\title{
Mengembangkan Pemahaman Konsep Siswa Menggunakan Model Inkuiri Terbimbing Sebagai Upaya Meningkatkan Prestasi Belajar Bimbingan Konseling
}

\author{
Desak Nyoman Suardani \\ SMA Negeri 1 Tegallalang \\ e-mail: desaknyoman45@gmail.com
}

\begin{abstract}
Abstrak
Penelitian ini bertujuan untuk meningkatkan prestasi belajar siswa Kelas XII IPA 1 Semester I SMA Negeri 1 Tegallalang Tahun Pelajaran 2018/2019 dengan jumlah siswa 24 orang yang prestasi belajar siswa yang secara umum masih belum mencapai ketuntasan belajar yang ditetapkan sekolah terhadap pelajaran 75,00 . Jenis penelitian ini adalah penelitian tindakan kelas yang terdiri dari perencanaan, pelaksanana tindakan, observasi, evaluasi dan refleksi. Penelitian ini dilaksanakan dalam dua siklus dengan tiga kali tatap muka untuk setiap siklus. Data prestasi belajar siswa dikumpulkan dengan mengunakan tes prestasi belajar sesudah diberikan pembelajaran melalui model inkuiri terbimbing untuk melatih pemahaman konsep siswa. Hasil penelitian menunjukkan adanya peningkatan pada prestasi belajar siswa dalam mengikuti pembelajaran Bimbingan Konseling untuk melatih pemahaman konsep siswa melalui inkuiri terbimbing. Pada siklus I diperoleh nilai rata kelas 74,66 dengan ketuntasan belajar sebesar $63,33 \%$. Pada siklus II perolehan nilai rata-rata kelas sebesar 82,33 dengan ketuntasan belajar sebesar $96,66 \%$. Jadi dari siklus ke siklus pembelajaran mengalami peningkatan sesuai dengan target pencapaian kurikulum yaitu ketuntasan belajar secara klasikal $85 \%$ dengan nilai minimal sebesar 75,00. Dari penelitian ini dapat disimpulkan bahwa penerapan menggunakan model inkuiri terbimbing dapat meningkatkan prestasi, prestasi belajar siswa terhadap bidang studi Bimbingan Konseling kelas XII IPA 1 SMA Negeri 1 Tegallalang.
\end{abstract}

Kata Kunci: Pemahaman Konsep, Inkuiri Terbimbing, Prestasi Belajar Bimbingan Konseling

\begin{abstract}
This study aims to improve the learning achievement of students of Class XII IPA 1 Semester I of SMA 1 Tegallalang 2018/2019 Academic Year with the number of students 24 people whose student achievement in general still has not achieved the learning completeness set by the school towards 75.00 lessons. This type of research is classroom action research consisting of planning, implementing action, observation, evaluation, and reflection. This research was conducted in two cycles with three times face to face for each cycle. Data on student learning achievement were collected using a learning achievement test after being given learning through a guided inquiry model to train students' understanding of concepts. The results of the study showed an increase in student learning achievement in participating in Counseling Guidance learning to train students' understanding of concepts through guided inquiry. In the first cycle, the average score of 74.66 was obtained with learning completeness of $63.33 \%$. In the second cycle, the acquisition of class scores was 82.33 with learning completeness of $96.66 \%$. So from the cycle to the learning cycle, there is an increase in accordance with the target of achieving the curriculum, namely learning completeness in a classical $85 \%$ with a minimum value of 75.00 . From this study it can be concluded that the application of using a guided inquiry model can improve achievement, student learning achievement in the XII IPA 1 class of Counseling Guidance in Tegallalang 1 State High School.
\end{abstract}

Keywords: Understanding of Concepts, Guided Inquiry, Counseling Guidance Learning Achievement 


\section{Pendahuluan}

Metode pembelajaran sangat dibutuhkan dalam sekolah, khususnya bagi pembelajaran di dalam kelas. Trianto (2010), menyebutkan bahwa model pembelajaran adalah suatu perencanaan atau pola yang digunakan sebagai pedoman dalam merencanakan pembelajaran di kelas atau pembelajaran tutorial. Pupuh dan Sobry S (2010) berpendapat makin tepat metode yang digunakan oleh guru dalam mengajar, diharapkan makin efektif pula pencapaian tujuan pembelajaran. Roestiyah (1989) mengatakan guru harus memiliki strategi agar anak didik dapat belajar secara efektif dan efisien, mengena pada tujuan yang diharapkan. Sebagai seorang tenaga pendidikan guru harus dapat menguasai keadaan kelas sehingga tercipta suasana belajar yang menyenangkan, untuk menghasilkan proses pembelajaran yang berkualitas, seorang guru membutuhkan metode pembelajaran yang baik pula, yang mampu memberikan dampak positif terhadap hasil belajar siswa, sehingga dibutuhkan kemampuan guru dalam menerapkan metode pembelajaran yang sesuai dengan karakteristik peserta didiknya (Kalsum ,2017).

"Pembelajaran inkuiri merupakan suatu rangkaian kegiatan belajar yang melibatkan secara maksimal seluruh kemampuan siswa untuk mencari dan menyelidiki secara sistematis, kritis, logis, analitis sehingga mereka dapat merumuskan sendiri penemuannya dengan penuh percaya diri”.Pendapat tersebut didukung Trianto (2009:166) mengemukakan bahwa sasaran utama kegiatan pembelajaran inkuiri adalah (1) keterlibatan siswa secara maksimal dalam proses kegiatan belajar, (2) keterarahan kegiatan secara logis dan sistematis pada tujuan pembelajaran, dan (3) mengembangkan sikap percaya pada diri siswa tentang apa yang ditemukan dalam proses inkuiri (Udiani ,2017).

Inkuiri terbimbing dengan tahaptahap pembelajarannya mampu melatih siswa dalam meningkatkan keterampilan proses sains (Wulanningsih, Prayitno, dan Probosari., 2012). Sintaks pembelajaran inkuiri terbimbing menurut Triyanto (2007) yaitu terdiri dari menyajikan masalah, membuat hipotesis, merancang percobaan, melakukan percobaan, menganalisis data, dan membuat kesimpulan. Dari sintak pembelajaran inkuiri tersebut memiliki potensi yang bermanfaat dalam meningkatkan keterampilan proses sains. Hal ini didukung oleh Zehra dan Nermin (2009) yang menyatakan bahwa inkuiri terbimbing mampu meningkatkan keterampilan proses siswa. Prosedur pembelajaran inkuiri terbimbing dilakukan dengan melibatkan siswa dalam penyelidikan, membantu siswa mengidentifikasi konsep atau metode, dan mendorong siswa menemukan cara untuk memecahkan masalah yang dihadapi. Guru berperan dalam memberikan masalah dan membimbing kegiatan pemecahan masalah (Prasetyo, 2015).

Model Pembelajaran Inkuiri (selanjutnya disebut MPI) adalah suatu model pembelajaran yang dikembangkan agar siswa menemukan dan menggunakan berbagai sumber informasi dan ide-ide untuk meningkatkan pemahaman tentang masalah, topik, atau isu tertentu. Penggunaan model ini menuntut siswa untuk mampu untuk tidak hanya sekedar menjawab pertanyaan atau mendapatkana jawaban yang benar. Model ini menuntut siswa untuk melakukan serangkaian investigasi, eksplorasi, pencarian, eksperimen, penelusuran, dan penelitian (Wahyuni ,2016).

Model pembelajaran inkuiri terbimbing memposisikan siswa untuk menyelesaikan permasalahan yang diajukan guru melalui pengajuan hipotesis, pengumpulan data, pengujian hipotesis melalui data yang dikumpulkan, sehingga pada tahap akhir siswa dapat menarik kesimpulan dari proses pembelajaran yang telah dilaksanakannya. Selain itu, terdapat beberapa kelebihan model pembelajaran inkuiri terbimbing, yaitu siswa dilibatkan secara aktif dalam memberikan dugaandugaan, menyelidiki, mengumpulkan beberapa data untuk membuktikan dugaandugaan, mengkomunikasikan bukti-bukti yang diperoleh dengan teman dan guru agar mendapat simpulan yang jelas dan tepat. Adanya kesempatan siswa untuk mengemukakan ide dan pola pikir dalam menyelesaikan masalah yang tertera pada kegiatan pembelajaran yang menggunakan model pembelajaran inkuiri terbimbing berdampak pada kebanggaan dan kepercayaan siswa terhadap dirinya karena siswa merasa dihargai keberadaannya dalam proses pembelajaran, sehingga meminimalkan kondisi banyak siswa yang mencontek atau tidak percaya terhadap kemampuannya (Azizah'Nur, 2016).

Keberhasilan pendidikan dapat ditunjukkan dari kualitas pendidikan yang ada, dimana kualitas pendidikan itu meliputi kualitas proses maupun kualitas lulusan. Jadi pendidikan dikatakan berhasil apabila proses belajar- mengajarnya berjalan dengan baik serta menghasilkan output yang berkualitas. Di dalam peningkatan mutu pendidikan perlu efisiensi pendidikan, yang mempunyai arti bahwa proses pendidikan harus mencapai hasil yang maksimal dengan biaya yang wajar (Maesaroh ,2013). 
Keberhasilan seorang guru dalam proses pembelajaran bukan hanya sekadar tercapainya suatu tujuan belajar, akan tetapi keberhasilan juga ditentukan oleh sejauh mana guru mampu mengembangkan kecakapan siswanya dalam menerapkan ilmu pengetahuan yang diperolehnya di sekolah untuk diterapkannya dalam kehidupan sehari-hari.

Menurut Tilaar (dalam Yamin dan Maisah, 2010: 29) menggambarkan profil guru yang profesional pada abad ke XXI sebagai berikut, (1) memiliki kepribadian yang matang dan berkembang, (2) memiliki penguasaan ilmu yang kuat, (3) memiliki keterampilan untuk membangkitkan minat peserta didik kepada ilmu pengetahuan dan teknologi, (4) mengembangkan profesi secara berkesinambungan.

Profesionalisme guru menjadi perhatian secara global, karena guru memiliki tugas dan peran bukan hanya memberikan informasiinformasi ilmu pengetahuan dan teknologi, melainkan juga membentuk sikap dan jiwa yang mampu bertahan dalam era hiperkompetisi. Sudarwan Danim (2003:192) menegaskan bahwa tuntutan kehadiran guru yang profesional tidak pernah surut, karena dalam proses kemanusiaan dan pemanusiaan, ia hadir sebagai subjek paling diandalkan, yang sering kali disebut sebagai Oemar bakri. Guru sebagai pendidik profesional mempunyai citra yang baik di masyarakat apabila dapat menunjukkan kepada masyarakat bahwa layak menjadi panutan sekelilingnya, masyarakat terutama akan melihat sikap dan perbuatan guru itu sehari- hari. Untuk menciptakan seorang guru yang profesional dalam melahirkan dan meningkatkan kualitas sumber daya manusia perlu dijelaskan dalam paper ini dari sudut profesionalisme guru dalam meningkatkan kualitas sumber daya manusia (Yusutria ,2017).

Menurut Wahyudi (2012) guru profesional adalah guru yang mampu mengelola dirinya sendiri dalam melaksanakan tugastugasnya sehari-hari. Profesionalisme yang dimaksud oleh mereka adalah satu proses yang bergerak dari ketidaktahuan menjadi tahu, dari ketidakmatangan menjadi matang. Sedangkan menurut Glickman dalam Bafadal yang menegaskan bahwa seseorang akan bekerja secara profesioanl bilaman orang tersebut memiliki kemampuan profesional bilamana memiliki kemampuan tinggi dan motivasi kerja tinggi (Fitriani ,2017).

Kompetensi guru terdiri atas empat, yaitu kompetensi pedagogik, kompetensi kepribadian, kompetensi sosial, dan kompetensi profesional. Indikator keempat kompetensi ini berjumlah 24 kemampuan ideal seorang guru profesional. Kompetensi pedagogik terdapat 10 indikator; kompetensi kepribadian terdapat 5 indikator; kompetensi sosial terdiri atas 4 indikator; dan kompetensi profesional terdiri atas 5 indikator. Sagala (2000) menyatakan, pengertian profesionalisme adalah "komitmen untuk ide-ide profesional." Sejalan dengan itu, Hasan (2013) juga mengatakan, sikap profesional merupakan bagian dari profesionalisme (Setiawan, 2017).

Penggambaran tersebut apabila dimiliki seorang guru akan membawanya untuk dapat memangku jabatan secara profesional sebagai seorang pendidik, pembimbing, pelatih, dan pemimpin yang dapat menciptakan iklim pembelajaran yang menarik, aman, dan nyaman serta kondusif bagi siswa. Dengan demikian, dapat dipastikan bahwa tingkat keberhasilan pencapaian semua harapan yang telah ditetapkan akan dapat terwujud secara optimal. Apabila guru telah memiliki pengetahuan dan pemahaman yang dipersyaratkan, sudah tentu dengan bekal ilmu pengetahuan yang dimilikinya dia akan mampu untuk berbuat sesuatu yang baru yang menjadi pengembangan dari hasil penggabungan pemahaman dengan tuntutan dunia baru. Dengan bekal pemahamannya seseorangguru akan terus berpikir secara kreatif dan kritis dalam setiap proses pembelajaran yang dilakukannya.

Namun terkadang, harapan tidak selamanya berjalan secara ideal dengan hasil yang diperoleh. Berbagai kendala harus dihadapi, dan berbagai rintangan harus dilalui. Seperti juga apa yang terjadi dengan pelaksanaan pembelajaran di SMA Negeri 1 Tegallalang. Berdasarkan observasi yang dilakukan pada siswa kelas XII IPA 1 semester I didapatkan bahwa prestasi belajar siswa untuk mata pelajaran Bimbingan Konseling tergolong masih rendah. Tidak sesuai dengan harapan tercapainya Kriteria Ketuntasan Minimal (KKM) mata pelajaran yang harus dikuasai siswa.

Beberapa kendala yang dapat diidentifikasi adalah dalam proses pembelajaran, rata-rata siswa yang bertanya ataupun menjawab pertanyaan yang diberikan guru hanya 5 sampai 10 orang, itu membuktikan bahwa tingkat keaktifan belajar siswa masih belum maksimal.Rendahnya tingkat keaktifan dan kreativitas siswa dalam belajar ini berpengaruh terhadap pencapaian prestasi belajar yang diperoleh. Bukti fisik berupa nilai ulangan harian setelah dilakukan tiga kali pertemuan menyimpulkan bahwa nilai rata-rata siswa hanya mencapai 69,16, di bawah rata-rata nilai KKM yang ditentukan di SMA Negeri 1 Tegallalang sebesar 75 . 
Mengingat kebutuhan siswa penguasaan pengetahuan pada tarap perkembangannya agar tidak terganggu proses perkembangannya berikutnya, guru mencoba mengatasi masalah tersebut dengan menerapkan strategi Inquiri Terbimbing.

Berladaskan kenyataan itulah guru sebagai peneliti mencoba menyusun sebuah alur penyelesaian masalah dan mendokumentasikannya menjadi sebuah penelitian ilmiah untuk dijadikan acuan bersama, dengan judul Meningkatkan Pemahaman Konsep Siswa Menggunakan Inkuiri Terbimbing Sebagai Upaya Meningkatkan Prestasi Belajar Bimbingan Konseling Siswa Kelas XII IPA 1 Semester I SMA Negeri 1 Tegallalang Tahun Pelajaran 2018/2019.

\section{Metode}

Dalam melaksanakan Penelitian Tindakan Kelas, langkah-langkah atau prosedur PTK didasarkan pada model rancangan PTK dari para ahli. Selama ini dikenal berbagai model PTK, namun pada dasarnya terdapat empat tahap yang harus dilalui yaitu (1) perencanan (planning), (2) pelaksanaan (acting), (3) pengamatan (observing), dan (4) refleksi (reflecting). Keempat tahap tersebut merupakan satu siklus dan akan dapat berlanjut kepada siklus kedua, siklus ketiga dan seterusnya sesuai dengan apa yang diinginkan dalam penelitian.

Untuk penelitian ini penulis memilih rancangan penelitian tindakan yang disampaikan Mc. Kernan seperti terlihat pada gambar berikut:

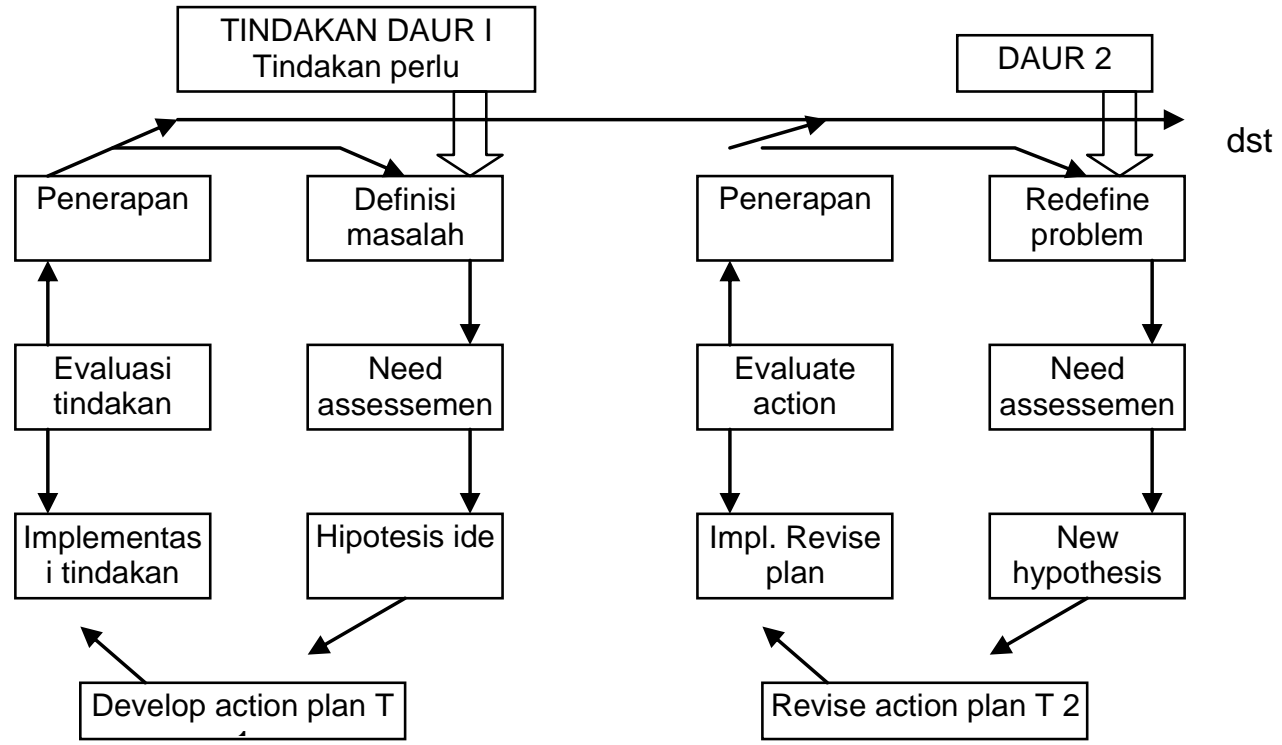

Gambar 1. Penelitian Tindakan Model Mc. Kernan, 1991 (Sukidin, Basrowi, Suranto, 2002)

Prosedur :

a) Tindakan daur I : mulai dari definisi masalah, berlanjut ke assessment yang disiapkan,berlanjut kerumusan hipotesis, berlanjut kepengembangan untuk tindakan I, lalu implementasi tindakan, evaluasi tindakan berlanjut ke penerapan selanjutnya.

b) Tindakan daur II : mulai dari menentukankembali masalah yang ada, berlanjut ke assessment yang disiapkan, terus kepemikiran terhadap munculnya hipotesis yang baru, perbaikan tindakan pada rencana ke 2, pelaksanaan tindakan, evaluasi terhadap semua pelaksanaan dan penerapan.

Sampel pada penelitian ini adalah siswa Kelas XII IPA 1 Semester I SMA Negeri 1 Tegallalang Tahun Pelajaran 2018/2019 dengan jumlah siswa 24 orang.Data prestasi belajar siswa dikumpulkan dengan mengunakan tes prestasi belajar sesudah diberikan pembelajaran melalui model inkuiri terbimbing untuk melatih pemahaman konsep siswa. Setelah data 
terkumpul, dilanjutkan dengan proses analisis data. Analisis data yang digunakan adalah analisis data deskriptif kuantitatif.

\section{Hasil dan Pembahasan}

a) Hasil yang diperoleh dari kegiatan awal:

Hasil yang menunjukan perolehan nilai rata rata kelas hasil belajar Bimbingan Konseling masih sangat rendah, yaitu dengan perolehan skor nilai secara klasikal yaitu 2075 dan rata rata kelas 69,16 , dimana siswa yang mencapai persentase ketuntasan belajar $33,33 \%$, dan yang tidak mencapai ketuntasan adalah $66,66 \%$, dengan tuntutan $\mathrm{KKM}$ untuk mata pelajaran Bimbingan Konseling kelas XII IPA 1 SMA Negeri 1 Tegallalang adalah dengan nilai 75.

b) Hasil pada siklus I:

Pada siklus I sudah diupayakan untuk perbaikan pembelajaran untuk meningkatkan hasil belajar Bimbingan Konseling dengan menggunakan model Inkuiri Terbimbing. Peneliti telah giat melakukan kegiatan yang susuai dengan kebenaran teori yang ada sehingga peneliti memperoleh hasil yang lebih baik dari proses awal, yaitu dengan rata rata nilai 74,66 dari jumlah nilai 2240 seluruh siswa di kelas XII IPA 1 SMA Negeri 1 Tegallalang, dan prosentase ketuntasan belajarnya adalah $63,33 \%$, yang tidak tuntas adalah $36,66 \%$. Hasil ini belum maksimal, karena belum mecapai indikator keberhasilan penelitian yang mencanangkan dengan minimal prosentase ketuntasan belajar $85 \%$.

c) Pada siklus II :

Dengan tindakan yang sangat maksimal dan pelaksanaan yang betul-betul mengikuti kebenaran teori sesuai dengan model pembelajaran Inkuiri Terbimbing dalam pembelajaran Bimbingan Konseling di kelas XII IPA 1 SMA Negeri 1 Tegallalang, dimana hasil yang diperoleh pada siklus II ini ternyata hasil belajar Bimbingan Konseling meningkat secara signifikan dengan nilai rata-rata 82,33 , dan ketuntasan belajarnya adalah $96,66 \%$.

Semua hasil yang diperoleh dari awal, siklus I dan siklus II digambarkan dalam bentuk tabel dan grafik seperti berikut:

Tabel 1 : Tabel Data Hasil Belajar Siswa kelas XII IPA 1 SMA Negeri 1 Tegallalang

\begin{tabular}{|c|c|c|c|c|}
\hline Data & Awal & Siklus I & Siklus li & Variabel \\
\hline Skor Nilai & 2075 & 2240 & 2470 & \multirow{3}{*}{$\begin{array}{l}\text { Hasil Belajar Bimbingan } \\
\text { Konseling } \\
\text { Dengan } \\
\mathrm{KKM}=75\end{array}$} \\
\hline $\begin{array}{l}\text { Rata } \\
\text { Kelas }\end{array}$ & 69,16 & 74,66 & 82,33 & \\
\hline $\begin{array}{l}\text { Persentase } \\
\text { Ketuntasan }\end{array}$ & $33,33 \%$ & $63,33 \%$ & $96,66 \%$ & \\
\hline
\end{tabular}

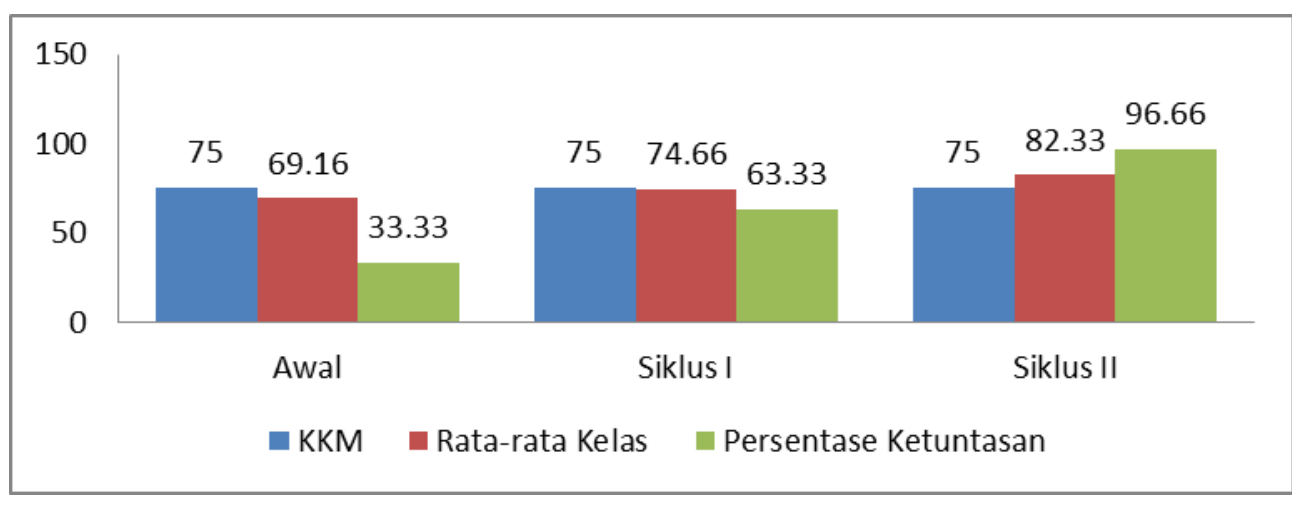

Gambar 2. Grafik Histogram Hasil Belajar Bimbingan Konseling siswa kelas XII IPA 1 semester I tahun pelajaran 2018/2019 SMA Negeri 1 Tegallalang

Inkuiri merupakan proses yang bervariasi dan meliputi kegiatan-kegiatanmengobservasi, merumuskan pertanyaan yang relevan, meng-evaluasi buku dan sumber-sumberinformasi lain secara kritis, merencanakan penyelidikan atau investigasi, mereview apa yangtelah diketahui, 
melaksanakan percobaan atau eksperimen dengan menggunakan alat untukmemperoleh data, menganalisis dan menginterpretasi data, serta membuat prediksi danmengkomunikasikan hasilnya (Depdikbud, 1997).

Menurut Sanjaya (2008), penggunaan inkuiri harus memperhatikan beberapa prinsip, yaituberorientasi pada pengembangan intelektual (pengembangan kemampuan berfikir), prinsipinteraksi (interaksi antara siswa maupun interaksi siswa dengan guru bahkan antara siswa denganlingkungan), prinsip bertanya (guru sebagai penanya), prinsip belajar untuk berfikir (learninghow to think), prinsip keterbukaan (menyediakan ruang untuk memberikan kesempatan kepadasiswa mengembangkan hipotesis dan secara terbuka membuktikan kebenaran hipotesis yangdiajukan).

Ada beberapa hal yang menjadi ciri utama Strategi Pembelajaran Inkuiri:

a) Strategi inkuiri menekankan pada aktivitas siswa secara maksimal untuk mencari dan menemukan, artinya peserta didik jadikan subyek belajar.

b) Seluruh aktivitas yang dilakukan siswa diarahkan untuk mencari dan menemukan jawabansendiri dari suatu yang dipertanyakan. Strategi inkuiri ini menempatkan guru sebagaifasilitator dan motivator, bukan sebagai sumber belajar yang menjelaskan saja.

c) Tujuan dari penggunaan strategi inkuiri adalah mengembangkan kemampuan berpikir secarasistematis, logis dan kritis atau mengembangkan kemampuan intelektual sebagai bagianproses mental.

Dari hasil observasi sebelum penelitian, didapatkan data awal yang memperoleh rata-rata sebesar 69,16. Hal ini menunjukkan bahwa kemampuan siswa dalam mata pelajaran Bimbingan Konseling masih sangat rendah mengingat kriteria ketuntasan belajar siswa untuk mata pelajaran ini di SMA Negeri 1 Tegallalang adalah 75,00. Dengan nilai yang sangat rendah seperti itu maka peneliti mengupayakan untuk dapat meningkatkan prestasi belajar anak/siswa menggunakan metode pembelajaran Inkuiri Terbimbing. Akhirnya dengan penerapan metode pembelajaran Inkuiri Terbimbing yang benar sesuai teori yang ada, peningkatan rata-rata prestasi belajar anak/siswa pada siklus I dapat diupayakan dan mencapai rata-rata 74,66. Namun rata-rata tersebut belum maksimal karena hanya 10 siswa memperoleh nilai di atas KKM sedangkan 20 yang lainnya belum mencapai KKM. Sedangkan prosentase ketuntasan belajar mereka baru mencapai $63,33 \%$. Hal tersebut terjadi akibat penggunaan metode pembelajaran Inkuiri Terbimbing belum maksimal dapat dilakukan disebabkan penerapan model/metode tersebut baru dicobakan sehingga guru masih belum mampu melaksanakannya sesua alur teori yang benar.

Pada siklus ke II perbaikan prestasi belajar siswa diupayakan lebih maksimal dengan peneliti membuat perencanaan yang lebih baik, menggunakan alur dan teori dari metode pembelajaran Inkuiri Terbimbing dengan benar dan lebih maksimal. Peneliti giat memotivasi siswa agar giat belajar, memberi arahan-arahan, menuntun mereka untuk mampu menguasai materi pelajaran pada mata pelajaran Bimbingan Konseling lebih optimal. Akhirnya dengan semua upaya tersebut peneliti mampu meningkatkan prestasi belajar siswa pada siklus II menjadi rata-rata 82,33 dengan presentase ketuntasan mencapai $96,66 \%$, hal ini menunjukkan terjadinya peningkatan yang sangat signifikan. Upaya-upaya yang maksimal tersebut menuntun pada suatu keberhasilan bahwa metode pembelajaran Inkuiri Terbimbing mampu meningkatkan prestasi belajar Bimbingan Konseling siswa kelas XII IPA 1 SMA Negeri 1 Tegallalang.

Hasil penelitian ini sejalan dengan hasil penelitian yang dilakukan oleh Murningsih pada tahun 2016 yang berjudul penerapan model pembelajaran inkuiri terbimbing untuk meningkatkan sikap ilmiah dan prestasi belajar kimia siswa. Hasil penelitiannya menunjukkan bahwa pencapaian sikap ilmiah pada siklus I sebesar $60 \%$ dan pada siklus II menjadi $93 \%$. Peningkatan prestasi belajar aspek pengetahuan pada siklus I diperoleh ketuntasan belajar sebesar $63 \%$ dan pada siklus II menjadi $93 \%$. Pada prestasi belajar siswa aspek sikap dan aspek keterampilan ketercapaian ketuntasan siswa pada siklus I sebesar $100 \%$,sehingga tidak dilanjutkan ke siklus II karena semua indikator sudah terpenuhi.

Selanjutnya penelitian yang dilakukan oleh Pratiwi pada tahun 2017 yang berjudul penerapan model pembelajaran inkuiri terbimbing untuk meningkatkan prestasi belajar siswa kelas VIII 3 SMP Laboratorium Undiksha. Hasil penelitiannya mendapatkan hasil bahwa: terjadi peningkatan prestasi belajar siswa, siklus I memiliki $\mathrm{KK}=21,21 \%$ dengan $=67,88$ dan $\mathrm{SD}=$ 6,25 , sedangkan siklus II memiliki $\mathrm{KK}=84,85 \%$ dengan $=80,45$ dan $\mathrm{SD}=7,94$. 2) tanggapan siswa terhadap penerapan model pembelajaran inkuiri terbimbing berkategori sangat positif dengan $=66,52$ dan $\mathrm{SD}=32,07$. 


\section{Simpulan dan Saran}

Simpulan yang dapat disampaikan berdasarkan semua hasil analisis data yang telah dilakukan dengan melihat hubungan rumusan masalah, tujuan penelitian, hipotesis tindakan dan semua hasil pembahasan adalah sebagai berikut:

Dari hasil refleksi yang telah disampaikan di Bab IV dan dengan melihat semua data yang telah dipaparkan, dapat disampaikan bahwa pencapaian tujuan penelitian di atas dapat dibuktikan dengan argumentasi sebagai berikut. a) Dari data awal ada 20 siswa mendapat nilai dibawah KKM dan pada siklus I menurun menjadi 11 siswa dan siklus II Hanya 1 siswa mendapat nilai di bawah KKM, b) Nilai rata-rata awal 69,16 naik menjadi 74,66 pada siklus I dan pada siklus II naik menjadi 82,33, dan c) Dari data awal siswa yang tuntas hanya 10 orang sedangkan pada siklus I menjadi lebih banyak yaitu 19 siswa dan pada siklus II menjadi cukup banyak yaitu 29 siswa.

Paparan di atas membuktikan bahwa metode pembelajaran Inkuiri Terbimbing dapat memberi jawaban sesuai tujuan penelitian ini. Semua ini dapat dicapai karena model/metode pembelajaran Inkuiri Terbimbing sangat efektif diterapkan dalam proses pembelajaran yang mengakibatkan siswa aktif, antusias dan dapat memahami materi yang diajarkan sehingga prestasi belajar siswa menjadi meningkat.

\section{Daftar Pustaka}

Azizah'nur Hani (2016). Pengaruh Model Pembelajaran Inkuiri Terbimbing Terhadap Kemampuan Berpikir Kritis Siswa Pada Materi Energi Bunyi . Jurnal Pena IImiah: Vol. 1, No. 1 (2016)

Basrowi dan Sukidin. 2002. Metode Penelitian Kualitatif Perspektif Mikro. Surabaya. Insan Cendikia.

Depdikbud. 1997. Kamus Besar Bahasa Indonesia. Jakarta: Balai Pustaka.

Fitriani (2017). Kompetensi Profesional Guru Dalam Pengelolaan Pembelajaran Di Mts Muhammadiyah Banda Aceh . Jurnal Magister Administrasi Pendidikan ISSN 2302-0156

Kalsum ,Mardiah (2017). Penggunaan Metode Pembelajaran Dalam Peningkatan Hasil Belajar Siswa . STUDIA DIDAKTIKA: Jurnal IImiah Bidang Pendidikan Vol. 11, No. 1, 2017; ISSN 1978-8169

Maesaroh , Siti (2013). Peranan Metode Pembelajaran Terhadap Minat Dan Prestasi Belajar Pendidikan Agama Islam . Jurnal Kependidikan, Vol. 1 No. 1 Nopember 2013

Murningsih, Ira Maya Tri, dkk. 2016. Penerapan Model Pembelajaran Inkuiri Terbimbing Untuk Meningkatkan Sikap IImiah Dan Prestasi Belajar Kimia Siswa. E-Jurnal Inovasi pendidikan IPA Vol 2 No 2.

Pratiwi, Ni Kadek Ratna, dkk. 2017. Penerapan Model Pembelajaran Inkuiri Terbimbing Untuk Meningkatkan Prestasi Belajar Siswa Kelas VIII 3 SMP Laboratorium Undiksha. E-Jurnal Pendidikan Fisika Undiksha. Vol 7 No 2.

Prasetyo, Idhun (2015). Penerapan Model Pembelajaran Inkuiri Terbimbing (Guided Inquiry) pada Materi Sistem Koordinasi untuk Meningkatkan Keterampilan Proses Sains pada Siswa Kelas XI IPA 3 SMA Batik 2 Surakarta Tahun Pelajaran 2013/2014 . Jurnal Pendidikan Biologi Volume 7,Nomor 2

Sanjaya, Wina. 2008. Perencanaan \& Desain Sistem Pembelajaran. Jakarta: Kencana. 
Setiawan ,Deny (2017). Urgensi Tuntutan Profesionalisme Dan Harapan Menjadi Guru Berkarakter (Studi Kasus: Sekolah Dasar dan Sekolah Menengah Pertama di Kabupaten Batubara) . Jurnal Fakultas IImu Sosial Universitas Negeri Medan

Udiani ,Ketut (2017). Pengaruh Model Pembelajaran Inkuiri Terbimbing Terhadap Hasil Belajar Ipa Dengan Mengendalikan Keterampilan Proses Sains Siswa Kelas Iv Sd No.7 Benoa Kecamatan Kuta Selatan Kabupaten Badung . e-Journal Program Pascasarjana Universitas Pendidikan Ganesha Program Studi Pendidikan Dasar (Vol 7, No 1 Tahun 2017)

Wahyuni ,Roni (2016). Pengaruh Model Pembelajaran Inkuiri Terbimbing dengan Metode Eksperimen terhadap Hasil Belajar Fisika Siswa Kelas XI IPA SMAN 2 Mataram Tahun Pelajaran 2016/2017 . Jurnal Pendidikan Fisika dan Teknologi (ISSN. 2407-6902)

Yamin, Martinis dan Maisah. 2010. Standarisasi Kinerja Guru. Jakarta: Persada. Press.

Yusutria (2017). Profesionalisme Guru Dalam Meningkatkan Kualitas Sumberdaya Manusia . Jurnal STKIP PGRI Sumatera Barat JI. Gunung Pangilun Padang Sumatera Barat Vol 2, No. 1 (2017) 